\title{
Opening Spaces for the Reading Audience: Fernando de Rojas's Celestina (1499/1502) and Niccolò Machiavelli's Mandragola (1518)
}

\author{
Sven Thorsten Kilian
}

$\mathbf{1}$

When Niccolò Machiavelli composed his most famous book, The Prince, c. 1513 , he concluded chapter 21 by stating that a prince, in order to make a name for himself and to be held in high esteem ('ut egregius habeatur'), should from time to time entertain his subjects with 'feasts and spectacles' ('feste e spettaculi'). Machiavelli, therefore, put things in a rather traditional way: he associated spectacles with religious or political — in other words exceptionaloccasions ('ne' tempi convenienti dello anno') and openly assigned them the function of controlling and canalising popular needs ('tenere occupati e' populi'), a function of spectacle that Juvenal had bitterly ridiculed in his tenth satire, coining the well-known phrase 'panem et circenses'. But Machiavelli's own comedy, Mandragola (1518), which figures among the most canonical texts of early modern Italy is, obviously, not to be reduced to this scheme of Realpolitik. It is, instead, a very different type of spectacle-one that is representative of a new generation of texts that Machiavelli and others came to institutionalise within the framework of their particular political and cultural contexts. ${ }^{1}$

One aspect of the early modern theatre's distancing from medieval theatre's religious and political functions - and from the forms of 'pure' entertainment condemned by Juvenal-is textuality, in its most precise and simple sense.

1 One should, of course, keep in mind that Juvenal's perspective is in opposition to that of Machiavelli: the Roman author criticises the public's impassiveness and its abstention from politics, qualifying the prince's 'thirst for glory' ('famae sitis'), which is analysed by Machiavelli as an aberration caused by the all-too-human lack of 'prudentia'. Cf. Niccolò Machiavelli, Il Principe, in Opere, ed. by Corrado Vivanti, 3 vols (Torino: Einaudi/Gallimard, 1997-2005), vol. I, chap. XXI, p. 182 (all references to Machiavelli are from this edition, and will be indicated by volume and page numbers); Iuvenalis, Saturae, ed. by Jakob Willis (Stuttgart: Teubner, 1997), X, pp. 132-50. Unless otherwise noted, all translations are my own. 
Whereas medieval feasts and ceremonies consisted of mostly unwritten protocols, theatre during the fifteenth century became more or less a stable text, as it had been in antiquity. In a great majority of cases, dramatic texts became printed books with relatively broad distribution, which makes 'theatre' more than the visual spectacle it had been for ancient Athenian or Roman citizens, namely a written medium that could be read by virtually anyone-anyone, that is, who was literate. Adopting this perspective means that the concept of theatre as a mass medium must be qualified, as people who could read these texts were few. This is why their function can be neither 'circensis' nor propaganda for the illiterate, as was that of the spectacles Machiavelli recommended to his prince and that of the moving pictures used during the twentieth century to educate the people of the newly created Soviet Union, for example. Plays like Mandragola were, instead, adapted to the needs of a reading elite rather than designed to entertain the masses. Nevertheless - and as distinct from medieval times - this literate elite can be considered a 'mass' audience insofar as it is heterogeneous, comprising all ages, classes, professions, and of course both sexes. This fact marks a clear shift with regard to monasteryconfined medieval literacy. Literacy, so to speak, became secular.

The thesis that I wish to advance in this paper, then, is that early modern dramatic texts should be regarded as books about books in an age when the material abundance of texts as well as their conceptual authority is becoming more and more problematic. In ancient and medieval times (cf. Seneca below) there can be no doubt about who the canonical authors were, but in early modern times this canon is undermined - not only but also because of the copia librorum produced by the printers' presses. The protestant slogan sola scriptura will be one answer to this problem. It is no surprise that it is specifically dramatic texts, out of the whole range of early modern textual production, that assume this reflective position, as they exist only on the grounds of an ontological paradox: they are texts that do not want to be texts and thus, with regard to other texts, dramatic texts can always stage themselves as other. They may even—implicitly or explicitly—articulate themselves as 'minor' in a Deleuzian sense, that is in a way that gives them claim to an extraterritorial position to which the standards and constraints of the majority do not apply. ${ }^{2}$ In terms of exploring how the spectator's and reader's experience of these dramas relates to the public spheres, one could say that they open a new space for a novel kind of reading public, not only by actually staging words in a

2 For the concept of the 'minor' in philosophy and literary studies, cf. Gilles Deleuze, 'Philosophie et minorité', Critique, 369 (1978), pp. 154-55; Gilles Deleuze and Félix Guattari, Kafka: pour une littérature mineure (Paris: Minuit, 1975). 
performance, but also by outlining a more or less anarchical space-one that is performative as well as typographical and material — for meta-textual reflection and for textual experiment in general. ${ }^{3}$

2

I will consider two well-known plays in order to support and illustrate these all-too-general theoretical observations. Machiavelli's Mandragola, the more recent one, has already been mentioned. The earlier one is Fernando de Rojas's Celestina, which was first published in 1499 as Comedia de Calisto y Melibea and was then expanded and re-edited in 1502, this latter being the version we still read today as tragicomedia. The book immediately became a bestseller in Spain and quickly achieved vast distribution there, not only in the intellectual centres of the time, like Salamanca, but also in the remote provinces of the realm and in the South American colonies. The colloquial title, $(\mathrm{La})$ Celestina, is documented from 1511 onward, which suggests that a considerable portion of the literate community read it and was confident that others would know

3 The vast bibliography of theoretical studies concerned with the themes of media history, genre, and textuality that are relevant to this study includes the following: Marshall MacLuhan, The Gutenberg Galaxy: The Making of Typographic Man (Toronto: University of Toronto Press, 1962); Frederic John Norton, Printing in Spain, 1501-1520: With a Note on the Early Editions of the "Celestina" (Cambridge: Cambridge University Press, 1966); Don William Cruickshank, '“Literature” and the Book Trade in Golden-age Spain', Modern Language Review, 73.4 (1978), pp. 799-824; Keith Whinnom, "The Problem of the "best-seller" in Spanish Golden-age Literature', Bulletin of Hispanic Studies, 57.3 (1980), pp. 189-98; Walter J. Ong, Orality and Literacy: The Technologizing of the Word (London: Methuen, 1982); Der Ursprung von Literatur: Medien, Rollen, Kommunikationssituationen zwischen 1450 und $165^{\circ}$, ed. by Gisela Smolka-Koerdt, (München: Fink, 1988); notably, in this latter volume, Roger Chartier, 'Entre littérature et lecture, la culture de l'imprimé', pp. 51-63; Donald C. Baker, 'When is a Text a Play? Reflections upon What Certain Late Medieval Dramatic Texts Can Tell Us', in Contexts for Early English Drama, ed. by Marianne G. Briscoe and John C. Coldewey (Bloomington: Indiana University Press, 1989), pp. 20-40; Hans Ulrich Gumbrecht, 'Buchdruck, "Literatur" und städtisches Milieu', in Eine Geschichte der spanischen Literatur, ed. by Hans Ulrich Gumbrecht (Frankfurt a.M.: Suhrkamp, 1990), pp. 175-221; Michael Giesecke, Der Buchdruck in der Frühen Neuzeit: Eine historische Fallstudie über die Durchsetzung neuer Informationsund Kommunikationstechnologien (Frankfurt a.M.: Suhrkamp, 1991); Hans Blumenberg, Die Legitimität der Neuzeit (Frankfurt a.M.: Suhrkamp, 1996); Jane Tylus, 'Theater and its Social Uses: Machiavelli's “Mandragola” and the Spectacle of Infamy', Renaissance Quarterly, 53.3 (2000), pp. 656-86. 
what they meant by phrases like 'el libro de Celestina', which we find in house inventories, for example. ${ }^{4}$

Despite its near-global dissemination, one must point out that the tragicomedia's European success originated in Italy—for obvious reasons of cultural hegemony and technological superiority. There also existed a direct and lively cultural exchange, in a very material sense, between Spain and Italy: some editions of Celestina in Spanish are thought to have been printed in Rome. Italy, after all, was mostly Spanish at that time: Milan was, at least temporarily, under Spanish influence; the Kingdoms of Naples and Sicily were ruled from 1505 by Fernando II de Aragón; the Papal States were, from 1492 to 1503, under the control of the Valencian Pope Alexander vi. Scholars conjecture that the translator of the first Italian Celestina (1506) had some function within the papal court. $^{5}$ A later edition of his translation (Venice, 1519) was the first to bear the title Celestina; the text then spread, with this title, to France, Flanders, and, finally, back to Spain. But Celestina was translated in other European countries (including Germany and England) as well, with the Italian version often being used as a reference. That Italians had access to the text at an early date may be borne out by Emma Scoles's supposition that a first (if incomplete) performance of the play occurred on the occasion of Lucrezia Borgia's (the pope's daughter's) marriage to Alfonso d'Este of Ferrara in 1501/2 in Rome, though no concrete evidence has been found. ${ }^{6}$ Nevertheless, Celestina's Italian reception can be dated, significantly, almost contemporaneously with its Spanish reception.

As is generally known, the play tells the story of Calisto, a young nobleman, who falls in love with Melibea, a girl of equal or higher social standing. He is helped to achieve his goal of seducing her by his servants Sempronio and Pármeno, who enlist the further assistance of an old bawd, Celestina. Celestina's negotiations are successful: Calisto and Melibea enjoy several sexual encounters in the garden of Melibea's family — a garden that he enters by climbing over a wall with a ladder. One night, Calisto, disturbed by a noise in the street, falls off the ladder and dies; his servants kill Celestina because she

4 Cf. Steven D. Kirby, ‘¿Quando empezó a conocerse la obra de Fernando de Rojas como "Celestina"?', Celestinesca, 13.1 (1989), pp. 59-62. For more general accounts of the question of the author and of the book's history, cf. Guillermo Serés, 'Fernando de Rojas y "La Celestina", in La Celestina: Tragicomedia de Calisto y Melibea, ed. by Francisco J. Lobera (Madrid: Real Academia Española, 2011), pp. 361-401.

5 Emma Scoles, 'Note sulla prima traduzione italiana della "Celestina", Studj romanzi, 33 (1961), pp. $153-217$.

6 Ibid., pp. 158-59, n. 2. 
does not want to share her reward with them, and they themselves are then publicly executed the next day. Melibea commits suicide and the play ends with her father Pleberio's now famous lament.

The two points I will explore over the following pages both relate to what could be called the play's reception history. The aim of these reflections is not, however, the history of reception as such; rather, I seek to functionalise reception history in order to provide a possible answer to the question of why Fernando de Rojas's text, which circulated in material form in relatively high numbers and at an elevated scale of distribution throughout Europe during the sixteenth century, was so immensely popular-and, more specifically, what function it could possibly have served for the contemporary reading public. This theoretical interest, furthermore, points us towards an at least partial account of the tragicomedia genre.

Two different spatial possibilities for reception - that is, two 'fictitious audiences' or 'dispositifs of reading' - are outlined in the play's prefatory letter and prologue, both based on the cultural sphere that the author addresses. ${ }^{7}$ In the prefatory letter, the author in fact casts himself, first of all, as a solitary reader, writing 'to one of his friends' ('a un su amigo') that he has often read and reread the first anonymous act of the play in solitary seclusion. ${ }^{8}$ Here we find the typical image of a thinker or rather a dreamer, inspired by or at least related to the traditional depiction of melancholy, a motif common to many other early modern reader-authors from Pico della Mirandola to Cervantes. Pico, of course, charges this dispositif with the potential for mystical enlightenment (or at least for reinforcement of faith) that is to be found mutatis mutandis in Luther's dogma of sola scriptura; ${ }^{9}$ in Cervantes we find the same motif in the auto-ironic self-portrayal of the Quijote's preface. ${ }^{10}$ At the same time, the

$7 \quad$ By using a variation of Walter Ong's ('fictitious audience') and Michel Foucault's (the French dispositif) terms I intend to describe the constitutive rather than accessory function of an implicit or explicit idea of whom a text is made for. This makes imagined audiences an important part of the text itself. Cf. Walter J. Ong, 'The Writer's Audience is Always a Fiction', PMLA, 90.1 (1975), pp. 9-21; Michel Foucault, 'Le jeu de Michel Foucault' [1977], in Dits et écrits, 4 vols (Paris: Gallimard, 1994), III, pp. 298-329.

'Asaz veces retraído in mi cámara, acostado sobre mi propria mano, echando mis sentidos por ventores y mi juicio a volar' (p. 5). Page numbers after Spanish quotations of the play refer to the 2011 edition; unless otherwise noted all translations are from Mack Hendricks Singleton, Celestina (Madison: University of Madison Press, 1958).

9 Cf. Pico della Mirandola, Oratio (sulla dignità umana), ed. by Pier Cesare Bori (Milano: Feltrinelli, 2000), § 43 .

10

Cf. 'estando una suspenso, con el papel delante, la pluma en la oreja, el codo en el bufete y la mano en la mejilla, pensando lo que diría'. The irony consists in the satirical 
prefatory letter makes a competitive claim. Its main function is to express that the text that follows-Celestina - should help to counter-balance the predominance of Italian cultural products. The metaphor of 'great armories of Milan' ('grandes herrerías de Milán', p. 6), which Rojas employs to describe the manufacturers of Italy's hegemonic 'culture industry', also anticipates the theme of the prologue: textual culture as battlefield.

It is in the prologue that we find a second description of a typical collective reading situation: Rojas tells us that, among a random group of ten people to whom his text is read, there will be 'quarrel' ('contienda', p. 15) concerning its meaning and value. One could, as has often been done, think of author-reader and reading group as emblematic of a medieval and a modern model of reading as such. Following Boccaccio's model, on the one hand, we find a small group of people listening to a storyteller or to a reader (the famous Florentine brigata). And, of course, the opening scene of Celestina has been interpreted as an indication that Rojas wrote his play not in order to be performed on stage but in order to be read aloud. The modern - that is, the solitary situation - on the other hand, shows a dispositif of reading like the one that can be found, for example, in Sebastian Brant's Narrenschiff (Ship of Fools, 1494), a text that opens with the self-ironising remarks of an overtaxed scholar lost in the librorum copia of his study. The quotation of both these models-the collective and the solitary one-in Celestina's introductory paratexts induce the reader to think of new types of reading, which allows for the merging and transformation of traditional mechanisms (dispositifs) of reading.

Both traditional dispositifs of reading (solitary, collective) and both types of audiences (homogeneous, heterogeneous), as well as the possibility for the text to be performed on stage indicate the differentiation of early modern audiences and their respective uses of text. Rojas's fictitious audience differs explicitly in one way from the Boccaccian model: Rojas's brigata of ten gathers together people of different views and conditions ('diez personas [...] en quien quepa esta differencia de condiciones', p. 20), ${ }^{11}$ whereas for Boccaccio

unmasking of the melancholic state of 'suspensión y elevamiento', since the author's friend, who comes to visit the writer in his study, immediately stigmatises his ruminations as 'sobra de pereza y penuria de discurso'. With regard to Celestina, it is important to underscore that the alleged disquiet is due to the lack of pedantic references ('la citación de los autores que los otros libros tienen') in the Quijote and its consequent lack of 'improviso autoridad': Miguel de Cervantes, Don Quijote de la Mancha (Madrid: Real Academia Española, 2004), pp. 7-14.

11 Singleton does not translate this phrase. Peter Bush in Celestina (Sawtry: Dedalus, 2009) gives it as 'ten people [...] and all have such different views', whereas the commentators of the 2011 Spanish edition explain the word 'condiciones' as 'caracteres o genios de los 
the group enjoyed a high degree of intimacy that naturally accompanied the fact that all members of the brigata were of 'noble blood' ('sangue nobile') and that their common condition allowed them to be of 'good' and 'pleasant company' ('buona' and 'bella compagnia') for each other. ${ }^{12}$ Rojas's parenthetical phrase 'as per usual' ('como suele acaescer', p. 13), however, underlines the hypothetical character of such a heterogeneous group and its experimental status. At the same time, such a group may indicate the social change, a century and a half after Boccaccio, that scholars have noted with regard to Celestina.13 The collective reception of a text, even if bound to a traditional model, had a different meaning in 1500: it points towards an increasingly public space within which words are staged - in more frequent theatre performances, for example - and reach heterogeneous audiences. The solitary dispositif of reading does not supplant the collective one. Instead, one dispositif reflects the other, solitary reading being nothing more than the spatiotemporal representation of an individual's particular way of understanding - if this understanding is envisioned as an imaginary space where multiple links to other spaces and times exist. I would argue, therefore, that Celestina is typical of the polyfunctional texts that we see emerging along a particular continuum of social demands that were triggered by relatively new constellations in the institutional context of early modern Spanish universities.

In terms of content, the demand for poly-functional texts like Celestina is twofold - which does not mean that the two levels of reception I am going to explore cannot overlap within the perspective of a single reader or within a group of readers or spectators. In fact, the possibility of reading from multiple perspectives is all the more significant because this possibility epitomises the openness and compatibility of different dispositifs of reading.

hombres' ('the character or intelligence of men'). There is no reason, however, why the notion of estate is not also implied, since the origin of the group members' differing views is explained via the traditional frame of the three ages of man, suggesting that interpretations of the text are clearly linked to the physical and social conditions of the reader. Cf. Giovanni Boccaccio, Decameron, ed. by Vittore Branca (Torino: 1980), p. 29 et passim.

13 The authoritative references here remain José Antonio Maravall, El mundo social de 'La Celestina' (Madrid: Ed. Gredos, 1964) and Stephen Gilman, The Spain of Fernando de Rojas: The Intellectual and Social Landscape of 'La Celestina' (Princeton: Princeton University Press, 1972). Newer publications also focus, interestingly, on the linguistic features of the text in relation to the social conditions of the characters. Dialogues devoid of meaning, for instance, are interpreted as symptoms of a precarious state of friendship under the conditions of social change: cf. Vicente Bernaschina Schürmann, 'Las políticas de la amistad en “La Celestina”: El caso de Pármeno', Celestinesca, 34 (2010), pp. 9-28. 
The first of these two levels of reception (academic on the one hand, rather aesthetic on the other) is directly linked to the scientific reading audience described in the prefatory letter. Scholars have convincingly shown that the rapid dissemination of Rojas's text and its numerous editions throughout Spain and Italy must have been supported or commissioned by an institution, and that the only one that could have taken an interest in doing so, at least in Spain, was the university. ${ }^{14}$ Celestina, in fact, could have been used and promoted by universities as a kind of innovative school book, not only because it consists of an abundance of 'philosophical sentences' ('sentencias filosofales'), motifs, and plot structures from the vast literature on the problems of bueno and loco amor (good and foolish love) as well as from humanist comedy, but also because the texture of these quotations is such that Rojas's text could speak to new educational models in the first half of the sixteenth century. There is evidence for Celestina's spreading use in Spanish universities that were partial to nominalism, inspired by what was emerging from the faculty of theology in Paris. Innovative Spanish endeavours concerning university education, like those of the rediscovered Ramon Llull, are of particular importance here. Llull's Catalan Arbre de ciència was printed in Latin translation as Arbor scientiae (Barcelona, 1482), and proposed in its penultimate chapter a so-called arbor exemplificalis that was meant to sum up the knowledge provided in the text by means of examples and proverbs. The teaching of morality via sentences and proverbs, on the one hand, and by philosophical reflection upon what is right and wrong, on the other, were pressing topics in Spanish academic programs. Celestina at times seems even to explicitly formulate a similar pedagogy when Sempronio recommends to his lovesick master Calisto that he 'read the historians, study the philosophers, heed the observations of the poets. Books are full of the vile and evil activities of women, and we may read many an account of the destruction of men like you who have attributed any value to them' ('Lee los historiales, estudia los filósofos, mira los poetas. Llenos están los libros de sus [i.e., de las mugeres] viles y malos enjemplos, y de las caídas que llevaron los que en algo, como tú, las reputaron', p. 39).

But, of course, if we consider Celestina as a whole, this educational program fails. That is why, once again, we cannot assign its function to this level

14 Cf., among others, the studies of José Luis Canet Vallés, in particular, “'La Celestina” y el mundo intelectual de su época', in Cinco Siglos de Celestina: Aportaciones interpretativas, ed. by Rafael Beltrán (València: Universitat de València, 1997), pp. 43-59; '“Celestina”: "sic et non": ¿Libro escolar-universitario?, Celestinesca, 31 (2007), pp. 23-58; “"La Celestina” en la "contienda" intelectual y universitaria de principios del s. XVI', Celestinesca, 32 (2008), pp. 85-107. 
of reception alone. Rojas's text, after all, is not only a compilation of intertextual quotes; it also questions the educational benefit of all these philosophical maxims. Indeed, it owes more to theological nominalism and scepticism than any teaching of moral philosophy could allow: its many quotations are contradictory and no one in Celestina is safe from desire, greed, or stupidity. The textual world of traditional advice, instructions, good models, and bad examples (all of which, in the era of print, are suddenly available to anyone who is able to read texts like the newly edited registers and indices of commonplaces - which Rojas would have used) are qualified by the play as a 'labyrinth of errors' and as 'deceptive' ('labirinto de errores';'engañoso', p. 340).In the two final — and gloomy - acts of Celestina ( $\mathrm{xx}$ and XxI), neither Melibea nor her father can remember any consolatory phrase they have read: 'My wounded mind in this affliction has quite forgotten them all' ('La dañada memoria con la gran turbación me les ha perdido', p. 334), says Melibea, before she jumps from the tower of her father's house. And her father searches in vain his 'fatigada memoria'- his reading memory, so to speak - in order to find comfort in an example of 'semejante dolor' (p. 341). ${ }^{15}$ The emblematic term designating the failure of reason in the face of the disorder and contingency of the world and of human nature, as well as linguistic attempts to appropriate this failure is, as Celestina says much earlier in the play, perplejidad (p. 112) - perplexity, or puzzlement and confusion.

Celestina's parody of this educational model, however, does not refer to the contents of the precepts alone, as we see in the mise-en-scène. Some of the most important sources of wisdom thus deployed not by a Llullian tree but by an entertaining play are Seneca's stoic principles-principles meant to provide orientation for the pupil who might find himself lost in the profusion of moral precepts. Self-containment in combination with close supervision by a teacher is what Seneca recommends in order to recognise and follow the moral code of the tried and tested authorities ('probati'). ${ }^{16}$ Among the

15 The literal translation of the former would be, of course, 'feeble' (Singleton) or 'tired' memory. Neither ancient nor contemporary (moral) literature provides examples of 'such' or 'similar' pain that could 'keep [Pleberio] company'.

16 Seneca, Ad Lucilium: epistolae morales, trans. by Richard M. Gummere (Cambridge: Harvard University Press, 1953), II, 4, p. 8. The textual transmission of this work was, of course, manifold and complicated. The epistolae were not read in comprehensive editions; rather, one would look up isolated quotations in compilations and textbooks. On this subject more generally, cf. Karl Alfred Blüher, Seneca in Spanien (München: Francke, 1969), and with regard to Celestina, Jacqueline Hamesse, Les Auctoritates Aristotelis: un florilège médiéval: étude historique et édition critique (Louvain: Publications Universitaires Béatrice-Nauwelaerts, 1974); Louise Fothergill-Payne, Seneca and 'Celestina' (Cambridge: 
numerous quotations from Seneca in Celestina, there are two that concern precisely this problem of moral guidance given the superabundance of sentences. In Seneca's text, the precepts read 'It is equally faulty to trust everyone and to trust no one' ('Utrumque enim vitium est, et omnibus credere et nulli', $A d$ Lucilium III, 4; p. 12) and 'Much harm is done by a single case of indulgence or greed [...]. Associate with those who will make a better man of you. Welcome those whom you yourself can improve. The process is mutual; for men learn while they teach' ('Unum exemplum luxuriae aut avaritiae multum mali facit [...]. Cum his versare, qui te meliorem facturi sunt. Illos admitte, quos tu potes facere meliores. Mutuo ista fiunt, et homines, dum docent, discunt', ibid., 7-8; pp. 32-34).

In Celestina, these quotations follow each other closely during the first encounter of Celestina and Pármeno that constitutes the last scene of act I. After a dialogue between Sempronio and Calisto that playfully inverts the hierarchy of master and servant, Celestina's ambiguously seductive instruction of her prodigal son Pármeno becomes yet another parody of authority as a social institution that is implied in all moral didacticism. In this context, Seneca's first maxim about trust only reveals the arbitrariness of the teacher's authority, since Celestina purports to provide Pármeno with the summum bonum ('buena dicha'), and that this is why he should believe her. It is unnecessary to stress that not even Epicurus plainly identified happiness with sexual satisfaction, as is the case here. Celestina thus epitomises a polemically distorted figure of Epicurean moral philosophy by translating Seneca: 'It is an exaggeration to believe everyone and an error to believe no one' ('Estremo es creer a todos y yerro no creer a ninguno', p. 76). In Celestina's mouth, the philosopher is transformed into what he himself fought against.

The rendering of the second precept is even more interesting because Rojas's - or the antiguo auctor's - translation not only distorts but thoroughly reverses the meaning of the precept within the phrase itself. In response to Celestina's attempt to get him on her side, Pármeno says, 'I have always heard

Cambridge University Press, 1988); Íñigo Ruiz Arzálluz, 'El mundo intelectual del “antiguo autor": las "Auctoritates Aristotelis" en la "Celestina" primitiva', Boletín de la Real Academia Española, 76.269 (1996), pp. 265-84. Fothergill-Payne provides the most comprehensive information. One cannot but agree with her interpretation of the tragicomedia as parody of moral philosophy and her persuasive description of Rojas's technique as an intertextual transformation of erudite quotes into 'small talk' (p. 46). Nevertheless, I intend to show that parody does not necessarily weaken the tragic character. On the contrary, Rojas's mocking of the Senecan model might be said to sharpen the pessimistic tendencies of Celestina, and it questions the efficiency of moral philosophy as a remedy to human mischief. 
my elders say that if we choose a model of lust or miserliness, it will do us much harm. It is also said that a man ought to be on good terms with someone who can improve him, and desert the company of those he feels he ought to improve' (' $\mathrm{O}$ h Celestina!, oído he a mis mayores que un enjemplo de luxuría o avaricia mucho mal hace, y que con aquéllos debe hombre conversar que le hagan major, y aquéllos dejar a quien él mejores piensa hacer', p. 76). Despite scholarly speculation about copying and typographic errors or misunderstandings due to the fragmentary reception of Seneca's works, ${ }^{17}$ I think that the intrinsic meanings of both the original and the translation are clear enough that we can see that, intentionally or not, the passage in Celestina marks a most significant distance from the Senecan model. Whereas Seneca, understandably, affirms the possibility and the duty of moral teaching, Rojas's tragicomedia rejects it on the basis of merciless individual self-determination. Not only must man himself decide the ethical value of his deeds, but also any attempt to improve another person is destined to fail: 'But Sempronio will not improve me by his example, nor shall I be able to help him overcome his defects' ('Y Sempronio, en su enjemplo, no me hará major, ni yo a él sanaré su vicio', p. 76).

If there is a contradiction between the didactic function of the play as claimed in its paratexts (and the repetition of this claim in Celestina's many translations) and its actual content, we should not dismiss the paratexts' stated didactic goals as mere literary camouflage. If we are to conjecture thoughtfully about the kind of pan-European demand Rojas's text met, it is not sufficient, I think, to label Celestina as an ingenious allegory of intertextuality and as a straightforward textbook parody. If this were the case, I would argue, the play would not have transcended the immediate milieu of its author. Instead, we might note that the comic display of stupidity and desire-driven behaviour, on the one hand, and the tragic absence - if not the actual negation — of hope, on the other, seem to have been ambiguously attractive to early modern European spectators and readers. The tragicomedia could thus be instructive-even, perhaps, edifying — without being pointedly didactic. I would furthermore suggest that the play's Italian reception (whether on stage or in print) may have helped its audience to perceive it as a play in the modern sense- that is, as text destined to be performed-since modern theatrical practice was, as we have seen, clearly more developed in the Italian city states and at the papal court than it was in Spain.

Alongside the somewhat radical nominalist position that there is no escape from the 'labyrinth of errors' in which human reason is imprisoned, Celestina 
explores a positive plaisir de texte, to use Roland Barthes's words. Aside from Melibea's and Pleberio's pain at the end of the play, there are other violent passions that resist linguistic representation throughout the text. At the end of act I, for instance, Calisto affirms the indescribable heat of his desire in front of his servant: 'The fire you are thinking of and the one I was referring to are as different from each other as appearance is from reality, or as a living thing is from its painted image, or as shadow is from substance' ('Como de la aparencia a la existencia, como de lo vivo a lo pintado, como de la sombra a lo real, tanta diferencia hay del fuego que dices al que me quema', pp. 33-34). These words, of course, must be read in the context of the figure of Calisto as parodic courtly lover. He is, like all the other characters in the play, depicted entirely via quotations like these. With regard to the blunt sexual nature of his desire, the Platonic distinctions between 'shadow' and 'substance' can only be interpreted as cynical. We might productively read this assertion in relation to a few others, in which the pleasure of communicating passion and desire is highlighted as the primary means to erotic gratification. For instance, in her ambiguously didactic conversation with Pármeno in act I, Celestina says that 'there is nothing more pleasurable than to enjoy sensual pleasures and to recount them and communicate them to friends' ('El deleite es con los amigos en las cosas sensuales, y especial en recontar las cosas de amores y comunicarlas', p. 77). And Sempronio informs Calisto again, in the second act:

[S]i perseveras, o de muerto o loco no podrás escapar, si siempre no te acompaña quien te allegue placeres, diga donaires, tenga canciones alegres, cante romances, cuente historias, pinte motes, finja cuentos, juegue a naipes, arme mates, finalmente que sepa buscar todo género de dulce pasatiempo para no dejar trasponer tu pensamiento en aquellos crueles desvíos que recebiste de aquella señora en el primer trance de tus amores. (p. 86)

If you persevere in this manner you will inevitably die or go mad. It is therefore necessary for you to have the companionship of someone who will entertain you, amuse you with jokes and jests, sing merry songs and ballads, paint mottoes, tell anecdotes and stories, play cards and chesssomeone who, briefly, will think up all sorts of quiet amusements to drive out of your mind those cruel disdains you have received from that lady in the first stage of your love affair.

Conversation and games are not just an adequate remedy against loco amor (foolish love). Instead, love is supposed to be talked about—it is made with the 
intent that it be talked about. Discourse on love and sex structures the whole play, from its ironic debates on moral philosophy to its suggestive dialogues. This discourse is simultaneously performed in a very obscene way, as in the famous act VII voyeurism scene with Celestina, Pármeno, and Areúsa, where Celestina induces her young companions to have sex before her eyes; or on the act XIX occasion of Calisto and Melibea's first sexual encounter. The combination of pleasure ('deleite', in its linguistic and bodily representation) and perplexity ('perplejidad', with its philosophical consequences that may lead to nihilist conclusions in the face of the challenge of contingency) ${ }^{18}$ in my view constitutes the deep structure that legitimises the play as tragicomedia. The parodic relationship between Calisto's behaviour and the abundantly quoted topos of courtly love remains as ambiguous as the link that emerges between the Senecan model of didacticism and Celestina's alleged pedagogical function. In both cases, individual judgement and agency are stripped of the restraints imposed by the guiding principles provided by traditional literary genres and textbooks. These models not only (or not even) are explicitly ridiculed, but also (and this, in a moral sense, is worse) are simply put out of reach, submerged in a seemingly unredeemable inflation of authority.

These observations might also lead us to understand another part of Celestina's success, particularly in Italy. I am thinking of the exuberantly creative and exclusively comic use to which authors like Pietro Aretino or Alessandro Piccolomini put the character Celestina as a model for their dialogues with female figures (Nanna in Aretino's Ragionamento, 1534; Raffaella in Piccolomini's La Raffaella. Ovvero Dialogo de la bella creanza de le donne, 1539). More than Spain, where we have few dramatic imitations and adaptations before the ideological turn of the Counter Reformation, Italy seems to have picked up and capitalised on the joyous core of Celestina. The partial functionalisation of the sexual and the more or less explicit misogyny that appears in Italian descendants of Celestina - features that withhold the tragic 'nihilism' of their model — would not be comic if the tragic were completely absent from the reader's mind. This fact may be illustrated by the semantic availability of biblical quotations both in Celestina and in Aretino's Ragionamento. For instance, 'Man shall not live by bread alone' (Matthew 4. 4; Luke 4. 4) is used by Aretino's character in order to justify, if not praise, prostitution. Significantly or not, his

18 Cf. Joachim Küpper, 'Mittelalterlich kosmische Ordnung und rinscimentales Bewußtsein von Kontingenz. Fernando de Rojas' "Celestina” als Inszenierung sinnfremder Faktizität (mit Bemerkungen zu Boccaccio, Petrarca, Machiavelli und Montaigne)', in Kontingenz, ed. by Gerhart Graevenitz, Poetik und Hermeneutik, 17 (München: Fink, 1998), pp. 173-223. 
text embarks on a kind of hermeneutic regression, the quotation of a quotation: Jesus referring to Deuteronomy (Deuteronomy 8. 3) and Deuteronomy referring to the earlier books of law. By re-quoting the gospel, Aretino reveals that the practice of (repeated) reference to an authority has the Bible as its model: the text of Celestina reads, for example, 'dijo que la sancta Escritura tenía' (p. 171). Aretino's 'ed ella a me: [...] dice il Vangelo in volgare, ${ }^{19}$ among many other similar introductory phrases, corresponds to the New Testament's recurrent anaphorical phrase 'it is written' ( $\gamma \varepsilon$ ' $p \alpha a \pi \tau \alpha \iota)$. Comic relief is produced by parody of this most authoritative model and, at the same time, tragic horror ( $\varphi o^{\prime} \beta 0 \varsigma$ ) emerges from the parodic distancing of the text at hand from the Bible.

The Italian example seems all the more valuable if we compare it to places where Celestina has no vibrant reception history - nations in which there was no space for this kind of parodic distancing. In Portugal, for example, Rojas's text was rejected precisely because of its obscenity, which was considered inappropriate for the noble Portuguese language. In Italy there was, in contrast, space for the obscene because of a higher permeability between institutions like local courts, the papacy, and the universities that was due both to political instability and to cultural hegemony. Because of its success in Italy, Celestina came to be known in France even before its translation into French since the Italian jurist Giovanni Nevizzano made abundant use of quotations from Rojas's text in his Latin legal treatise on marriage, Sylva nuptialis (1521). Celestina for Nevizzano seemed to be the single most detestable model for obscene language and imagination. In these circumstances, however, obscenity actually became a positive force in the circulation of material from one nation to another in early modern Europe.

The second text I will discuss was originally written — not only popularisedin Italy, and it cannot be situated within the group of obscene and/or misogynist texts mentioned above. Machiavelli's Mandragola was likely first written and performed in 1518 , though it may have been composed much earlier. ${ }^{20}$ It was published immediately after its performance and is one of only three

19 Pietro Aretino, Ragionamento (Milano: Rizzoli, 2001), Seconda giornata, p. 160.

20 Mario Martelli, '“La Mandragola” e il suo prologo', in Il Teatro di Machiavelli: Gargnano del Garda, 30 Settembre-2 Ottobre 2004, ed. by Gennaro Barbarisi and Anna Maria Cabrini (Milano: Cisalpino/Monduzzi, 2005), pp. 221-55. Martelli dates the writing of Mandragola back to the year 1504 , when the plot is said to take place. 
Machiavellian works published during his lifetime (The Prince was published posthumously, five years after his death, in 1532). One should mention this fact, I think, in order to understand that it is not just that Machiavelli's comedy was popular at the time, but also that the publication of a dramatic text seems to have been a rather secure economic enterprise. This occurs, of course, because the reading public and the play's audience merge such that the fame of the spectacular staging helps promote the book sales.

In the case of Mandragola, we lack the descriptions of either the reading (and writing) dispositif or of the fictitious audience that appear in Rojas's text. Machiavelli's famed letter to Francesco Vettori, the Florentine ambassador to the Roman court (1o December 1513), which evokes the performance of transgression that was enacted every evening by the exiled diplomat crossing the threshold of his study, applies in all its humanist refinement to the writing of Il Principe and to the author's preliminary or simultaneous readings. ${ }^{21}$ But the pathos of the conversation with the ancients, which Montaigne and other solitary writers undertake, also seems out of place when we consider a secular production like Mandragola. The part of humanist role-playing in adequate costume is more obvious here than it is in Rojas, and its meaning is fundamentally different: whereas Rojas writes about his work on Celestina as a distraction from his main occupations - note the parallel participles 'retraído' (p. 5) and 'distraído' (p. 7) in his dedicatory letter-Machiavelli writes in anticipation of a future compensation for his exile. He thus considered The Prince to be central to his potential for employment: 'If the manuscript were read, it would become evident that in fifteen years of study of the art of the state I did neither sleep nor gamble' ('Quando la [i.e., 'la cosa', that is, the manuscript of The Prince]

21 'Venuta la sera, mi ritorno a casa, et entro nel mio scrittoio; et in su l'uscio mi spoglio quella veste cotidiana, piena di fango e di loto, e mi metto panni reali e curiali; e rivestito condecentemente, entro nelle antique corti degli antiqui uomini, dove, da loro ricevuto amorevolmente, mi pasco di quel cibo, che solum è mio, e che io nacqui per lui; dove io non mi vergogno parlare con loro, e domandarli della ragione delle loro azioni; e quelli per loro umanità mi rispondono; e non sento per 4 hore di tempo alcuna noia, sdimentico ogni affanno, non temo la povertà, non mi sbigottisce la morte: tutto mi transferisco in loro' ('In the evening I go back home and enter my study. In the entrance I take off these everyday clothes full of mud and dirt and I put on royal and courtly robes. Dressed properly I enter the ancient courts of the ancient people and kindly welcomed by them I feast on that food that solely belongs to me and for whom I was born. There I do not feel ashamed to speak with them and to ask them the reason for their actions. And because of their humanity they reply to me; and for a four-hours time I do not feel any concern, I forget about every anxiety, I do not fear poverty, death does not dismay me, I completely move into them'). Opere II, pp. ${ }^{295}{ }^{-96 .}$ 
fussi letta, si vedrebbe che quindici anni che io sono stato a studio all'arte dello stato, non gl'ho né dormiti né giuocati'). ${ }^{22}$ Of course, we can find in this letter something of the motive Freud detected in all literature - the compensation for the frustration of everyday life that imagination provides. ${ }^{23}$ Here, this compensation is oriented towards the reading dispositif rather than towards the fictitious world of a poetic creation. Only when he was about to be 'dressed properly' again - that is, returned to Florence-did Machiavelli compose (or at least launch a first staging of) Mandragola, and the public he must have envisioned was more homogeneous than that of Rojas, since Florence already had its theatre scene. ${ }^{24}$ At first glance, consequently, Mandragola seems to be much more conventional and, in its Florentine institutional context, a rather pleasant textual product. In contrast to Rojas, Machiavelli staked the popularity of his play on a contemporary model of success in order to re-establish his reputation..$^{25}$ Apart from the authors' individual interests, then, the differences in form and genre between our two texts can be explained even more convincingly if we consider them in the context of the audience's offers and demands according to the availability of these literary forms in different areas of the contemporary cultural net. The hegemonic culture of Italy's leading city-states had an established tradition upon which an author like Machiavelli could draw with relatively little effort, whereas in Spain the desire to distinguish oneself from the hegemonic model ('the armories of Milan') and the postulation of authenticity (of the antiguo auctor's creation) led to tentative and hybrid forms like the tragicomedia.

The plot of Mandragola is even more straightforward than that of Celestina: Callimaco, a young man, falls in love with Lucrezia, a married Florentine woman. He is helped to achieve his goal of seducing her by a loyal servant and male go-between named Ligurio. By fooling Lucrezia's husband, Messer Nicia, Callimaco introduces himself into their house and persuades Lucrezia of his qualities as a lover. The happy ending consists in a rather lubricious arrangement for all three: Callimaco becomes Nicia's man-friend (and the homoerotic pleasure, at least of his eyes) as well as Lucrezia's lover, with full access to the couple's house.

\footnotetext{
22 Ibid., p. 297.

23 Sigmund Freud, 'Der Dichter und das Phantasieren' ['The Creative Writer and Daydreaming', 1907/o8], in Studienausgabe (Frankfurt a.M.: Fischer, 1969), X, pp. 169-79.

24 Cf. Ludovico Zorzi, 'Firenze: il teatro e la città', in Il Teatro e la città: saggi sulla scena italiana (Torino: Einaudi, 1977), pp. 61-234.

25 Francesco Bausi, 'Machiavelli e la commedia fiorentina del primo cinquecento', in Il Teatro di Machiavelli, pp. 1-20.
} 
The structural parallel with Celestina is obvious, even if the connection should not be overstated since the subject is a common one. Indeeed, Mandragola's plot is simply a rearrangement of motifs and narrative fragments that can all be found in Boccaccio's novellas: the Decameron's innamoramento di fama (I. 5; IV. 4; VII. 7); the instrumentalisation of greedy and simpleminded clerics for unholy purposes (III. 3); and the consenting cuckold (II. 9; III. 4; and, above all, v. 10). In moral terms, as well, Celestina's joyous cynicism is not precisely Machiavellian. Indeed, the relationship between Rojas's Celestina and Machiavelli's Mandragola has been probed by very few scholars and with feeble results. ${ }^{26}$ Machiavelli might have known Celestina and Rojas might explore a kind of Machiavellian reasoning avant la lettre in his play, but the decisive difference between the two texts is the tragic failure of reason in Celestina and its comic, yet amoral success in Mandragola. Or rather, to put it in the terms of The Prince: all of Rojas's characters lack the virtù they need in order to prevail against fortuna, whereas Callimaco and his companions use their virtù against fortuna with infallible efficacy. On this broader level of moral and political philosophy, Rojas and Machiavelli thus give two opposing answers to the same question.

A closer look at the public Machiavelli envisages for his play reveals another clear reference to Boccaccio. Like the fourteenth-century author (in both the Elegia di Madonna Fiammetta and in the Decameron), the speaker of Machiavelli's prologue addresses a female audience with a suggestive undertone:

Una giovane accorta [Lucrezia]

fu da lui [Callimaco] molto amata,

e per questo ingannata

$\mathrm{fu}$, come intenderete, ed io vorrei

Che voi fussi ingannate come lei.

He greatly loved a prudent young woman and tricked her, as you will learn, and I hope you'll be tricked as she was. ${ }^{27}$

26 Louise Fothergill-Payne, "'La Celestina” como esbozo de una lección maquiavelica', Romanische Forschungen, 81.1 (1969), pp. 158-75; Benito Brancaforte, “'La Celestina” y “La Mandragola”: la razón como medio de corrupción', Bulletin of Hispanic Studies, 47·3 (1970), pp. 201-09.

27 Machiavelli, La Mandragola, in Opere III, p. 142. For the English translation, cf. Machiavelli, The Chief Works and Others, trans. by Allan Gilbert (Durham: Duke University Press, 1965), II (emphasis added). 
This theatrical and sexual inganno comes again into question at the end of act IV, when the monk says that 'tonight nobody will sleep' ('in questa notte non ci dormirà persona'), 'this night' referring to the one during which Callimaco and Lucrezia first have intercourse and to the narrative ellipse between the two last acts of the performance. Much has been written about the rather disproportionate temporal ratio of staging and plot, ${ }^{28}$ but the main reason for this imbalance - which is repeated in Machiavelli's second comedy Clizia — is that the obscene is indirectly brought on stage by exciting the audience's imagination and by accompanying the narrated event with a performative effect. Here I must stress the gender marking of the prologue because it leads us to the competition among media (novella versus play) inscribed in Machiavelli's text: his female audience is an audience of novella readers that now is meant to be captivated by the sex appeal of the performance. The philocaptio acted upon Melibea by Celestina is thus transformed by Machiavelli in a seduction strategy aimed at the not-only-female audience, implying a kind of lascivious gender blurring.

This teasing strategy defines the structure of the play. Messer Nicia, the deceived husband, epitomises the ridiculous dottore archetype that is found in commedia dell'arte. I would argue, though, that genre-typical mockery (uccellamento) in Mandragola is not only more subtle, but also corresponds with political philosophy. This brings us to another striking similarity between the two plays: in Celestina's aforementioned voyeurism scene, the old woman pushes Pármeno into bed with Areúsa and tells him: 'Now come here, you backward, bashful boy. I want to see whether you have anything in you before I go. Get in the bed there and play with her' ('Llégate acá, negligente, vergonzoso, que quiero ver para cuánto eres ante que me vaya. Retózala in esta cama', p. 181). At the beginning of act $\mathrm{v}$ in Mandragola, Messer Nicia tells us what has happened on the night when no one could sleep. He describes how he himself made the young man (whom he didn't recognise as Callimaco) undress, and praises the body he touched: 'You never saw finer skin, white, soft, smooth [...]. Since I'd put my hands into the dough, I wanted to go to the bottom of it; then I wanted to see if he was healthy' ('Tu non vedesti mai le piú belle carni: bianco, morbido, pastoso! [...]. Poi che avevo messo mano in pasta, io ne volsi toccare el fondo; poi volsi vedere s'egli era sano' (v. 2, p. 182). Like Rojas, Machiavelli brings on stage an obscenity with all the more comic effect insofar as it is contrasted with error and deceit. He goes even further, however, by directly

28 Machiavelli, in fact, contravenes the rule of the unity of time, an irregularity that, on the one hand, he and his contemporaries must have been aware of, but that, on the other hand, was often broken. Cf. Bausi, pp. $7-8$. 
involving his audience in the game, thereby making evident a crucial aspect of early modern theatre that is only latent in Celestina, namely the pleasure of being deceived. Both Lucrezia and her husband receive compensation (that is, Callimaco) for having been mocked, just as the audience enjoys the play. Eventually, the epistemological difference between Lucrezia's dis-inganno and Messer Nicia's remaining-in-error comes together in the lieto fine, the happy end for all.

One can easily observe a superficial link between this final lesson of Mandragola and the most controversial eighteenth chapter of The Prince, 'How Princes Should Keep Their Promises' ('Quomodo fides a principibus sit servanda'). Two anthropological assumptions are to be found in this chapter. The first regards a critique of popular absent-mindedness that is similar to Juvenal's: 'a prince who deceives always finds men who let themselves be deceived' ('colui che inganna troverrà sempre chi si lascerà ingannare'). The second focuses more on individual psychology: 'Everybody sees what you appear to be; few perceive what you are, and those few dare not contradict the belief of the many, who have the majesty of the government to support them' ('Ognuno vede quello che tu pari, pochi sentono quello che tu se'; e quelli pochi non ardiscano opporsi alla opinione di molti che abbino la maestà dello stato che li difenda'). ${ }^{29}$ What reading Mandragola in this context shows is that deceit may have its utility, even for the person deceived (in this case Messer Nicia), ${ }^{30}$ a didactic message that is very different from that expressed by Juvenal. Nevertheless, one must problematise the relationship between drama and political theory rather than take it for granted. Why might this be? The first reason lies within political philosophy itself: if Machiavelli in Dell'arte della guerra (publ. 1521) stigmatises frequent theatre visits in ancient Greece as decadent behaviour that leads only to military and political defeat ('Anything that makes men delicate or unwarlike'; 'Alcuna cosa che faccia gli uomini delicati e imbelli' $)^{31}$ this half-sarcastic, half-mocking representation of a particular historic situation being employed as a biting comment on contemporary

29 Il Principe, in Opere I, p. 166. For the English translation, cf. Machiavelli, trans. by Gilbert, I. The translation of the Latin title of this chapter seems misleading but, in fact, fides refers both to religion and to personal credibility here.

30 Cf. Jean-Claude Zancarini, " "Ridere delli errori delli huomini." Politique et comique chez Machiavel', in Il Teatro di Machiavelli, pp. 99-124: 'la tromperie peut servir l'intérêt de tous, trompés comme trompeurs' (p. 104).

31 Dell'arte della guerra, VII, in Opere I, pp. 688-89. For the English translation, cf. Machiavelli, trans. by Gilbert, II. 
Italy should not be mistaken for a verdict on theatre and comedy as such. ${ }^{32}$ However, theatre practice in Dell'arte as well as in The Prince (as noted in the introduction to this essay) is clearly allocated to the realm of otium, whereas political philosophy (including the martial arts) deals, obviously, with the most esteemed form of negotium, that is the business of the polis. The second reason for my pleading in favour of a clear distinction between Machiavelli's political and theatrical writings is that of the obvious and yet often underestimated difference of genre. The tendency of a reader today to pass over this difference originates in eighteenth-century aesthetics of autonomy and, all the more, in the relativist claims of the postmodern era. Prior to our age, cultural and artistic practices were per se rooted in institutional and social settings that defined them more fully than the actual form of their products. What I attempt to show here, however allusively, is that Machiavelli, in the writing of his comedies, operates on a field different from political philosophy. He fully adopts the conventions of this field, and Mandragola therefore cannot be interpreted as a simple mise-en-scène of his political philosophy. ${ }^{33}$

32 Cf. Zancarini, p. 111. The text of chapter viI of Dell'arte della guerra reads: 'interverrà allo stato suo [i.e., to the one who will follow the martial rules expressed in the book] come al regno de' macedoni, il quale, venendo sotto a Filippo che aveva imparato il modo dello ordinare gli eserciti da Epaminonda tebano, diventò, con questo ordine e con questi esercizi, mentre che l'altra Grecia stava in ozio e attendeva a recitare commedie, tanto potente che potette in pochi anni tutta occuparla' ('It will happen to his state as to the kingdom of the Macedonians when ruled by Philip, who learned the method of organizing his army from Epaminondas the Theban. While the rest of Greece sat idle or busied herself in the acting of comedies, Philip by means of this organization and these exercises became so powerful that in a few years he could entirely conquer her', p. 689).

33 It is striking that approaches that try to adopt a mise-en-scène presupposition need either neglect or disregard the conventional aspects of the play, whether with regard to plot structures or to characters. Even if some of the findings of these approaches are appealing, they remain precarious because of their ahistoricity. See, for example, Palmer and Pontuso's intriguing proposal that Messer Nicia is the actual mastermind of Mandragola's plot, namely that he is the 'Prince' of the play — an idea that is acceptable only if one discards the (in my view irrefutable) genre-typical nature of this character as originating in the commedia dell'arte dottore mask: Michael Palmer and James F. Pontuso, "The Master Fool: The Conspiracy of Machiavelli's "Mandragola"', Perspectives on Political Science, 25.3 (1996), pp. 124-32. A merging of dottore and prince and, consequently, of uccellamento and virtù is, of course, thinkable, but only from an anachronistic perspective. An additional challenge to this hypothesis is that speculations about Mandragola's precise composition date abound, and include dates as wide-ranging as 1504 to 1518 . If the play really is meant to be a mise-en-scène of the author's philosophy, however, it can only have been written after The Prince (cf. for instance Patricia Vilches, 'The Delegate Womb: Lucrezia's Body as 
These objections against an all-too-easy parallel between Machiavelli's political and dramatic production are not intended to invalidate every link between The Prince and Mandragola; they simply make things more complicated. An axiom that holds true in political philosophy might prove unlikely to apply in entertainment practices. This is precisely the case here. Whereas the political use of deception helps the ruler to achieve his goals under the condition that his subjects be deceived positively — that is, unconsciouslyaesthetic inganno provides pleasure to a conscious audience. Deception in theatre requires the willing suspension of disbelief. Messer Nicia might be the victim of a lewd game (he does, after all, appear as ignorant of what is happening as he was before the play began), but he also seems to get what he wants: not only an heir but also some homoerotic pleasure. The Boccaccian models suggest that a deliberate ménage à trois is absolutely envisageable for the contemporary audience. Of course, a Messer Nicia would never admit this in public...

Celestina and Mandragola, then, open spaces for a new reading public in at least three ways: first, with regard to the texts themselves; second, with regard to their imagined audiences; and third, with regard to their onstage performance.

Much has been said concerning the originality of Celestina's form, combining, as it does, aspects both of the novella tradition and of humanist comedy. Even more important, I would argue, is the fact that the text is a compilation of innumerable quotes from tracts on moral philosophy. By reassembling them in the form of a novelistic drama, Rojas implicitly creates a meta-language of moral philosophy that did not previously exist. At the same time, he transforms comedy in a genuinely 'early modern' way by challenging its didactic function. In contrast, Mandragola maintains the traditional form of Italian comedy. Nevertheless, it problematises the notion of the lieto fine (happy ending) by emptying it of its moral content. What Machiavelli's play seems to suggest is that aesthetic pleasure, which is distinct from political well-being, comprises the audience's consent to be deceived. Mandragola proposes, in other words, an early aesthetics of illusion.

What I have tried to show about these authors' imagined public is an assumption about the plays' implicit spectators/readers rather than an account of

Political Tool in Machiavelli's “La Mandragola”, American Journal of Italian Studies, 22.60 (1999), pp. 99-125 (p. 102). 
actual reception. Both Celestina and Mandragola presuppose well-read audiences precisely in order to challenge traditional reading habits. In the case of Celestina, this applies primarily to an academic audience of scholars and students, but the fact that the text is without doubt accessible to other audiences as well permits the opening of a new space in which eclectic readings become possible for the whole literate world. Mandragola, instead, is performed on everyday occasions. With its quasi-political subtext it informs a most uncommon space within the concerns of men and women, the powerful, and the subordinate. By transposing political practice from the polis onto the stage and into the play as text, Mandragola furthermore transforms such practice into an aesthetic rather than a political lesson.

Consequently, and this is my final and perhaps most speculative point, dramatic texts (whether witnessed as performances or read as books) are one of the main agents by which these new spaces are opened in the early modern period. Plays are widespread, short, and cheap, and eventually they don't even have to be read. These features make dramatic texts the fitting answer to the copia librorum that was often complained about, especially after Gutenberg's invention. Celestina and Mandragola are thus, in my view, prominent and influential examples of the process of trans-institutional and social mixing that is fundamental for the development of early modern and modern theatre as a mass medium. 